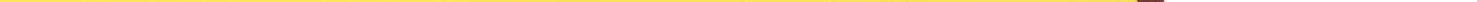




\section{Guidance and Counselling}

\section{Editor}

Dr Marilyn Campbell

\author{
School of Learning \\ and Professional Studies \\ Queensland University of Technology
}

\section{Associate Editor}

Dr Linda Gilmore

\section{Book Review Editor}

Dr Louise Mercer

Queenaland Univervity of Tecbnology

\section{Editorial Board}

Dr Mary McMahon

Dr Nadine Pelling

Dr Ken Glasgow

Dr Susan Colmar

Dr Michael Faulkner

Mr Michael Durrant

Dr Kathryn Geldard
Queensland University of Technology

University of Queensland

University of Soutb Australia

University of Western Australia

University of Sydney

La Trobe Univervity

University of Sydney

University of the Sunsbine Coast

\section{Australian Guidance Counselling Association Limited Executive Members

$\begin{array}{ll}\text { President } & \text { Lesley Fraser } \\ \text { Secretary } & \text { Paul Kelly } \\ \text { Treasurer } & \text { Jim Phillips } \\ \text { Memberstip Secretary } & \text { Coosje Griffiths } \\ \text { Newsletter Editor } & \text { Michael Faulkner } \\ \text { Journal Editor } & \text { Marilyn Campbell } \\ \text { Immediate Past President } & \text { Grania McCudden }\end{array}$

$\begin{array}{ll}\text { State Representatives } \\ \text { New Soutb Wales } & \text { Susan Colmar } \\ \text { Victoria } & \text { Sandra Groves } \\ \text { Western Australia } & \text { Catherine Schelfhout } \\ \text { Queensland } & \text { Ed Riley } \\ \text { Soutb Australia } & \text { Royce Herbert } \\ \text { Tasmania } & \text { Sandra Wiggins } \\ \text { Australian Capital Territory } & \text { Jenny Lang } \\ \text { Nortbern Territory } & \text { Bettina Bettington }\end{array}$

The Australian Journal of Guidance and Counselling presents articles of relevance to all areas of guidance and counselling. Papers may address theoretical, practical, professional or training issues and may focus on educational or psychological topics.

Invitation to contribute and information for authors are printed on the inside back cover.

\section{Subscription Rates 2009}

This journal is published biannually.

\section{Individual}

$\begin{array}{ll}\text { Australia } & \$ 34.50 \\ \text { Overseas } & \$ 47.00\end{array}$

\section{Institutions}

$\begin{array}{ll}\text { Australia } & \$ 63.50 \\ \text { Overseas } & \$ 84.00\end{array}$

All prices are in Australian dollars and include economy air postage and GST where applicable.

Orders and subscription enquiries should be addressed to:

Journal subscriptions

Australian Academic Press

32 Jeays Street

Bowen Hills Qld 4006 Australia

Journal subscription is covered by membership to the Australian Guidance and Counselling Association. For all enquiries, please contact the association:

PO BOx 2072

KELVIN GROVE QLD 4059

Australia
Published for the Australian Guidance and Counselling Association Ltd by AUSTRALIAN ACADEMIC PRESS: 32 Jeays Street Bowen Hills QLD 4006, Australia

www.australianacademicpress.com.au 